\title{
ІМПЛЕМЕНТАЦІЯ ДОСВІДУ КРАЇН ЄС В ПРОЦЕСІ УДОСКОНАЛЕННЯ ДЕЦЕНТРАЛІЗАЦЇ̈ ПУБЛІЧНОЇ ВЛАДИ ТА АДМІНІСТРУВАННЯ В УКРАЇНІ.
}

Багмет M.O., д-р іст. наук, професор, Інститут державного управління, Чорноморський національний університет імені Петра Могили, м. Миколаїв, Україна

Штирьов О.М., канд. наук з держ. упр, доцент, Інститут державного управління, Чорноморський національний університет імені Петра Могили, м. Миколаїв, Україна

Гаргаун Я.І., канд.іст., наук, Інститут державного управління, Чорноморський національний університет імені Петра Могили, м. Миколаїв, Україна

У статті здійснено дослідження досвіду країн ЄС щзодо проведення реформи децентралізачіï, а також можливості його імплементації в Украӥні. Крім того, дослідження містить в собі аналіз впровадження в практику європейських критерїв та стандартів в процесі децентралізації публічної влади та адміністрування в Україні. Автори статті акиентують увагу на необхідності запозичення Україною саме європейського досвіду, доводять, щзо Україна готова здійснювати реформу децентралізації публічної влади та адміністрування. Авторами насамперед акиентована увага на вдосконаленні правової та інституційної бази системи міжбюджетного фінансування. Зауважено щзо наступним кроком повинна стати робота науковців щуодо розробки методики розрахунку фiнансування регіонів. Також авторами пропонується внести зміни до законів «Про місиеве самоврядування в Україні» та «Про місиеві державні адміністрації», де вказані повноваження місцевих органів, методика визначення обсягів фінансування, а також визначено 
поняття «комунальна власність» та «комунальне майно». Зазначено, щуо для кожного рівня органів місчевої влади потрібно окреслити коло відповідальності та міри покарання, так як контроль та відповідальність є підгрунтям децентралізащії. В результаті цих втілення зазначених пропозищій щуодо фінансової децентралізації очікується створення нової системи місцевих бюджетів та міжбюджетних відносин, в основі яких повинна бути інституційна симетрія, щуо передбачає поєднання та взаємозв'язок економічних суб' єктів, які користуються суспільними благами, сплачують податки, і тих, хто приймає самостійно рішення про ї̈ надання.

На основі проведеного дослідження зроблено висновки, що імплементація позитивного зарубіжного досвіду сприятиме становленню громадянського суспільства, так як успішність реформи децентралізащії публічної влади та адміністрування є запорукою розвитку свободи, демократії та громадянського суспільства в Україні.

Ключові слова: децентралізація, реформа, краӥни ЄС, Украӥна, імплементація, європейські критерї та стандарти, громадянське суспільство.

Постановка проблеми у загальному вигляді. Децентралізація публічної влади та адміністрування в останні декілька років стали дуже актуальною та популярною темою, як серед зарубіжних і вітчизняних науковців, так і серед політичних діячів та громадських діячів. До того ж, цей тренд стосується не лише держав з усталеними демократичними традиціями, а й країн колишнього соціалістичного табору, де довгий час мало місце централізоване авторитарне управління, зокрема і в питаннях місцевого розвитку. Стратегічний курс України, направлений на європейську інтеграцію, вимагає сучасної моделі публічного управління. Досвід європейський країн вдало демонструє, що саме децентралізація публічної влади та адміністрування є найефективнішим інструментом модернізації державного управління. Проте в Україні на практиці децентралізація та розвиток територіальних громад довгий час не сприймалися як серйозний чинник розвитку країни в цілому. 
Аналіз останніх досліджень і публікацій. Питання становлення місцевого самоврядування в Україні розглядається в працях відомих вчених: В. Погорілка, М. Пухтинського, А. Ткачука. Аналізом теоретичного та практичного значення місцевого самоврядування приділили увагу В. Авер'янов, В. Бакуменко, В. Барвінський, О. Бориславська, М. Братковський, Л. Беззубко, І. Грицяк, В. Гройсман, Б. Данилишин, Е. Заверуха, I. Захарченко. Базисні складові нормативно-правових аспектів децентралізації висвітлено в працях Л. Бабич, С. Балацького, О. Батанова, Н. Бикадорової, А. Буковинського, О. Свтушенка, А. Крат, В. Ємельянова, Т. Тарасенка, А. Шульги.

Організаційно-управлінський аспект формування структури місцевого самоврядування в Україні досліджували В. Бабаєв, О. Бобровська, С. Болдирєв, А. Дєгтяр, О. Демченко, А. Гошко, Я. Жовнірчик, В. Матвієнко, К. Яковенко.

Формулювання цілей статті (постановка завдання). В процесі дослідження були поставлені наступні завдання:

- дослідити та узагальнити стан розробленості проблематики у науковій літератури вітчизняними та зарубіжними вченими;

- здійснити аналіз законодавчих інновацій процесу децентралізації влади в українському суспільстві;

- проаналізувати імплементування досвіду країн ЄС щодо позитивних результатів фінансової децентралізації влади.

Виклад основного матеріалу дослідження. В Україні, як і в переважній більшості країн сучасного світу, відбуваються кардинальні зміни в усіх сферах суспільного життя, зумовлені процесами глобальних соціально-економічних та цивілізаційних трансформацій. Такі глобальні виклики актуалізують необхідність проведення системних реформ, спрямованих на модернізацію українського суспільства та держави, забезпечення збалансованого поступу країни як високорозвиненої, правової, цивілізованої європейської держави 3 високим рівнем життя населення, соціальною стабільністю, сталою демократичною традицією. Однією з таких реформ є реформа децентралізації децентралізації публічної влади та адміністрування.

Насамперед треба зазначити, що Європейська хартія місцевого самоврядування підкреслює, що «органи місцевого самоврядування 
є однією з головних підвалин будь-якого демократичного режиму», а «право громадян на участь в управлінні державними справами $\epsilon$ одним із демократичних принципів, також визначає що «існування органів місцевого самоврядування, наділених реальними повноваженнями, може забезпечити ефективне і близьке до громадянина управління» [21].

Початок реформи децентралізації в Україні було оголошено процесом реформування місцевого самоврядування. Зокрема, 1 квітня 2017 року Урядом України було ухвалено «Концепцію реформи місцевого самоврядування та територіальної організації влади» [10]. Відповідно до цієї Концепції, передбачалося створення спроможних територіальних громад, за умови передачі повноважень та ресурсів органам місцевого самоврядування (сільським та міським радам). Тобто територіальна децентралізація, як сучасна реформа адміністративно-територіального устрою базується на двох принципових умовах іiі проведення: реформування адміністративно-територіальних утворень повинне відбуватися шляхом добровільного об'єднання територіальних громад (ОТГ); нові ОТГ повинні бути спроможними надавати якісно нові суспільні послуги.

На сьогодні умови територіальної децентралізації забезпечуються цілою низкою нормативно-законодавчих документів: Закон України «Про співробітництво територіальних громад» від 17.06.2014 № 1508-VII; Закон України «Про добровільне об’єднання територіальних громад» від 05.02.2015 № 157-19; Методика формування спроможних територіальних громад, Постанова КМУ від 08.04.2015 р., № 214; Закон України «Про внесення змін до Бюджетного кодексу України щодо реформи міжбюджетних відносин» від 26.04.2015, підстава 288-19 та ін [9].

У всіх розвинених країнах $Є С$ головне завдання влади полягає у задоволенні проблем інститутів громадянського суспільства за допомогою місцевого самоврядування. Проблему якісного задоволення таких потреб допомагає вирішити децентралізація, оскільки децентралізація означає передачу права приймати рішення органам, які не підпорядковані центральним органам влади і яких обирають зацікавлені громадяни. Проблематика децентралізації як одного із засобів 
підвищення ефективності функціонування публічної влади вже впродовж тривалого часу перебуває в полі зору вітчизняних науковців та експертів. Це зумовлено, зокрема, успішною реалізацією засади децентралізації у практиці більшості держав Свропейського Союзу.

Аналіз систем місцевого самоврядування європейських країн показує, що у світі існує декілька їх моделей, які істотно відрізняються одна від одної за принципами формування органів місцевого самоврядування, типом взаємовідносин органів місцевого самоврядування $з$ органами державної влади, формами взаємодії представницьких і виконавчо-розпорядних органів у системі місцевого самоврядування [6].

Основним критерієм типологізації при цьому виступає функціональне взаємовідношення та розподіл компетенції між центральними (державними) та місцевими органами управління [17].

Англосаксонська модель (Великобританія) передбачає обрання в усіх адміністративно - територіальних одиницях представницьких органів на строк, як правило, не більше трьох років. У невеликих адміністративно - територіальних утвореннях до цього органу входять 3-5 осіб, у великих - до 50 осіб. Місцеві представницькі органи формально виступають як функціонуючі автономно в межах наданих їм повноважень, і пряме підпорядкування нижчестоящих органів вищестоящим не запроваджується. Крім представницького органу населення обирає безпосередньо деяких посадових осіб. У містах представницькими органами або безпосередньо населенням обираються мери. У першому випадку діяльність цієї посадової особи жорстко контролюється представницьким органом, у другому - вона наділяється значно ширшим колом повноважень.

Для англосаксонської моделі характерною є відсутність на місцях повноважних представників центральної влади. Теоретично провести розмежування між функціями держави і місцевого самоврядування у цьому випадку не складно: уряд держави і підпорядковані йому державні органи управління діють на виконання здебільшого загальнонаціональних, політичних завдань (оборона, зовнішні відносини, загальнодержавні фінансові ресурси, визначення національних пріоритетів), у той час як повсякденні, поточні 
управлінські функції (освіта, охорона здоров'я, соціальна допомога та захист, забезпечення громадського порядку, утримання автошляхів, житлово-комунальне господарство) передані місцевій владі [2].

Існує певна ізольованість політичних процесів на національному та місцевому рівні. Крім того, урядові органи не вправі прямо контролювати місцеві співтовариства, оскільки останні виступають як повністю автономні колективи, що діють у деяких випадках як рівні з державою суб'єкти. Контроль за діяльністю органів місцевогосамоврядування здійснюється переважно опосередкованим шляхом: через центральні міністерства та судові органи. У зазначеній моделі місцевого самоврядування $є$ як позитивні, так і негативні сторони. 3 одного боку, місцеві справи повністю передаються у відання населення адміністративно - територіальних одиниць та обраних ним органів та посадових осіб. 3 другого ж - це забезпечує максимальну децентралізацію в управлінні державою, що ускладнює узгодженість рішень на різних рівнях системи управління та знижує ефективність ії функціонування, створюючи підстави для різного роду зловживань. Вибори, що проводяться дуже часто, різко знижують політичну активність громадян.

Друга - континентальна модель - представлена у Франції, Італії, Фінляндії та деяких інших країнах. Вона заснована на поєднанні, 3 одного боку, виборності всіх представницьких та виконавчих органів на первинному рівні самоврядування (у громадах, комунах) та, $з$ другого - призначення з «центру» на місця повноважних представників державної влади (комісарів, префектів тощо) на регіональному рівні. На цих осіб покладається здійснення контрольної функції щодо дотримання законності органами місцевого самоврядування нижчестоящого адміністративно-територіального рівня, санкціонування рішень муніципальних представницьких органів, а також виконання інших функцій загальнодержавного характеру. Таким чином, адміністративна, організаційна та фінансова автономія місцевого самоврядування хоча й існує, але значно обмежена і перебуває під контролем державних органів. Дана модель забезпечує більшу централізацію системи управління. Проте в останні роки можна спостерігати пом'якшення адміністративної опіки з боку держави [3]. 
На відміну від країн з англосаксонською моделлю місцевого самоврядування в державах, де запроваджена континентальна модель, органи місцевого самоврядування можуть брати участь у здійсненні влади на загальнонаціональному рівні. Так, у Франції муніципалітети беруть участь у виборах сенату - верхньої палати парламенту, оскільки їх делегати представляють більшу частину відповідних виборчих колегій.

Ще одна модель умовно може бути названа іберійською, оскільки вона отримала поширення в Іспанії та Португалії. Тут на всіх рівнях адміністративно-територіального устрою держави $\epsilon$ виборні представницькі органи та головні посадові особи місцевого самоврядування, що очолюють виконавчі органи (алькальди, регідори, мери, префекти тощо). Введення посад спеціально призначених уповноважених представників центральних органів державної влади за цією моделлю не передбачається, але така обрана посадова особа затверджується урядом як представник держави в адміністративно-територіальній одиниці з правом контролю за діяльністю представницького органу. У розвинутих демократичних країнах відмінності між вказаними моделями не мають принципового характеру. Можна навіть говорити про певне зближення між ними - вони базуються на багатьох близьких принципах, основою місцевого управління визнаються представницькі органи, що формуються населенням у результаті вільних та демократичних виборів.

У багатьох країнах Свропейського Союзу секторальне (галузеве) законодавство передбачає створення постійно діючих консультативних органів за участю відповідних інститутів громадянського суспільства (захист прав споживачів та довкілля, охорона здоров'я тощо), що відіграють ключову роль у процесах прийняття рішень органами державного управління у відповідних секторах/галузях. У деяких сферах такі органи (що об'єднують представників урядових структур та інститутів громадянського суспільства) мають законодавчо визначені повноваження брати участь в управлінні й проводити моніторинг реалізації політики у певній сфері (наприклад, в управлінні соціальною або пенсійною політикою). 
Якщо порушуються визначені положення й вимоги щодо проведення публічних консультацій, такий регуляторний інструмент скасовується в судовому порядку. Як правило, в таких випадках лише відповідні інститути громадянського суспільства (а не окремі громадяни) мають право звертатися до суду з позовом щодо скасування таких скасування таких механізмів реалізації політики від імені фізичних і юридичних осіб, на права й інтереси яких вони мають або можуть мати вплив. Вибір певного механізму (або їх комбінації), так само, як і їхня відповідна послідовність на різних стадіях процесу прийняття рішення, залежить від низки факторів, що включає: сферу дії і тип рішення щодо політики; роль органів державного управління у відповідній сфері; роль різних зацікавлених груп.

У деяких країнах Європейського Союзу законодавство загального спрямування, що регулює діяльність уряду, органів державного управління та держадміністрацій, містить конкретні положення й вимоги щодо проведення публічних консультацій, особливо це стосується процесу розробки й прийняття підзаконних актів та інших регуляторних інструментів/механізмів для реалізації державної політики, визначеної і впроваджуваної урядом або парламентом.

Реформи у Франції певною мірою стосувалися розширення субнаціональної автономії, скорочення функцій центрального уряду, ослаблення ролі префектів та створення автономного регіонального рівня. Найбільш централізована в минулому держава Франція, кількість самоврядних одиниць (комун) якої сягає нині 36 тис., за економічним потенціалом посідає четверте місце в світі. У 2002 році Франція прийняла закон, відповідно до якого створюються так звані агломерації, тобто об'єднання населених пунктів, об'єднання комун. 3 одного боку, це сприяє вирішенню проблем, які цікавлять жителів сусідніх громад, а 3 іншого - дозволяє економити державний ресурс і створює умови для того, щоб територія сама заробляла кошти, тобто, створює умови для саморозвитку.

Загалом державна політика Франції у справі організації місцевого самоврядування реалізується у двох основних напрямах: деконцентрація - більш широке делегування державою своїх адміністративних функцій на місцях, а також деконцентралізація - пере- 
дача державою частини своїх владних повноважень місцевим органам самоврядування [1, с. 247].

Для України цей досвід $є$ повчальним, бо протягом останньої чверті минулого сторіччя самоврядування Франції отримало більше автономії щодо ресурсів та легітимності. 3 одного боку, держава закликає на великий шлях - запроваджуються нові форми діяльності органів місцевого самоврядування: великі міста отримують істотніший вплив, оскільки їх структура більше відображає сучасне суспільство країни, нові форми громадської участі підтримуються національним законодавств. 3 іншого боку, залишається певна напруга у відносинах між центральною та місцевими владами. Вона очевидна у використанні цільових грантів та системи контролю над місцевими бюджетами. Однак у місцевому самоврядуванні Франції вже працюють нові підходи публічного управління, 3 наголосом не тільки на контроль місцевих фінансів, а й на ефективність діяльності органів місцевого самоврядування та витрачання суспільних коштів.

Конституція Франції досить скупо говорить про місцеве самоврядування: «Місцевими колективами Республіки є комуни, департаменти, заморські території. Всі інші місцеві колективи утворюються законом. Ці колективи вільно управляються виборними радами на умовах, визначених законом. Представники Уряду в департаментах і територіях відповідають за національні інтереси, адміністративний контроль і дотримання законів [11, с. 44].

Отже, як і Україна, Франція тривалий час була централізованою державою. Вона пережила 25-річний процес децентралізації, який уже практично завершено. Франції знадобилося багато років послідовної децентралізації, щоб побутові послуги перетворилися на справжнє зобов'язання органів місцевого самоврядування. Цього було досягнуто шляхом запровадження нормативної системи фінансового зрівняння, яка забезпечила реальну досяжність національних стандартів, попри розбіжності в базах місцевих надходжень [1, с. 249].

Корисним досвідом вважаємо також досвід Республіки Італія. Організація влади та розподіл повноважень була запроваджена 3 прийняттям Конституції 01.01.1948 (до того Італія формально була Колоніальною Імперією Муссоліні, а перед тим - Королівством). На 
початку 2000 років була проведена грунтовна реформа 3 децентралізації та реорганізації влади, внаслідок якої 2001 року до Конституції було включено нову Главу (Titolo V) щодо Регіонів, Провінцій та Комун. У цій Главі зокрема визначено, що Республіка складається із Комун, Провінцій, Міст-Метрополій, Регіонів та Держави. Таким чином традиційна ієрархічна структура вертикалі замінена на систему рівнозначності усіх елементів Республіки. Організація державної влади далі описується від найнижчого рівня комуни, котрий $є$ найближчим до громадян і до рівня центрального уряду, що опікується найбільш комплексними питаннями [3].

У 2009 році в Латвії була завершена децентралізаційна реформа, яка охоплювала три основні напрями: юридичний, адміністративнотериторіальний та фіскальний. При цьому слід звернути увагу на те, що кожен напрям реформування проводився відокремлено, а механізми його реалізації не узгоджувалися з іншими. Початком юридичної реформи в Латвії стало прийняття в 1994 р. закону «Про місцеве самоврядування», який визначав сутність, основні права та обов'язки, а також фінансову базу місцевого самоврядування. Характеризуючи адміністративно-територіальну реформу, варто відмітити, що, незважаючи на невеликі розміри території країни, для Латвії на початку реформ був характерний нерівномірний розвиток іiі регіонів та територій. Модель адміністративно-територіального устрою того часу була успадкована від Радянського Союзу, а ії подрібненість стояла на заваді уніфікації передачі повноважень. Основною метою проведення адміністративно-територіальної реформи стало створення адміністративних територій із місцевим та регіональним самоврядуванням, які можуть економічно розвиватися і забезпечити надання якісних послуг населенню [20, с. 3].

Однак упровадження адміністративно-територіальної реформи проходило зі значними труднощами. Насамперед вони стосувалися небажання дрібних громад об'єднуватися. За перші шість років реформи утворилося лише 20 об'єднаних громад. При цьому помилкою з боку держави стало те, що не було затверджено чітких правил щодо критеріїв та формату об'єднання. Це призвело до того, що нові громади хоч і виникали, але були неспроможні виконувати 
необхідні функції. Що стосується фінансової реформи, то протягом 1995-1998 рр. були прийняті закони «Про бюджети самоуправлінь» та «Про фінансове вирівнювання ресурсів самоуправлінь». На сьогоднішній день основними джерелами доходів місцевих бюджетів у Латвії є податкові надходження, трансферти з державного бюджету, місцеві мита, взаєморозрахунки місцевих спільнот, плата від послуг. Основну питому вагу у структурі надходжень займає податок із доходів фізичних осіб, який розподіляється між державним та місцевим бюджетами. Значну частину займає також податок на нерухомість, який розраховується виходячи з кадастрової вартості. Бюджетне вирівнювання діє з 1995 р., але збалансування бюджетів відбувається лише частково [18, с. 24].

Загалом слід відмітити, що, незважаючи на тривалий термін упровадження, децентралізаційна реформа в Латвії вирішила широке коло існуючих проблем та сприяла збільшенню можливостей місцевого самоврядування у вирішенні найбільш нагальних питань та посилила їх вплив на місцевий економічний розвиток.

На основі аналізу досвіду країн Прибалтики. можна виокремити основні шляхи впровадження реформ 3 децентралізації влади в Україні:

- розмежування повноважень, прав та обов'язків різних рівнів влади відповідно до сутності правової, демократичної держави та громадянського суспільства, що дозволить досягти балансу інтересів у системі публічних відносин;

- розробка та реалізація ефективної регіональної політики, спрямованої на забезпечення рівномірного місцевого і регіонального розвитку;

- забезпечення втілення принципу субсидіарності як способу подолання конфлікту інтересів між місцевими органами виконавчої влади та органами місцевого самоврядування;

- упровадження адміністративно-територіальної реформи iз забезпеченням збереження цілісності держави та іiі унітарного устрою;

- забезпечення розширення прав територіальних громад щодо вирішення проблем їх життєзабезпечення; 
- проведення бюджетної реформи з урахуванням загальнонаціональних та місцевих інтересів [17, с. 282].

Досить цікавим вважаємо досвід проведення децентралізації в Республіці Польща. Ключовими моментами в реформуванні публічного управління в Польщі є децентралізація та субсидіарність. В Конституції Польщі задекларовано унітарний устрій держави. В розділі 1 ст.15 Конституції у контексті децентралізації публічної влади і впровадження в адміністративному поділі країни автономних одиниць задекларовано, що принцип унітарної держави не є для децентралізації влади перешкодою та гарантується територіальним устроєм Польщі. Закладений принцип децентралізації публічної влади в Польщі став основою проведення адміністративно-територіальної реформи [23].

У Концепції реформування місцевого самоврядування та територіальної організації влади в Україні зазначено шлях та способи адміністративно-територіального реформування, що грунтується на розмежуванні повноважень у системі органів місцевого самоврядування та органів виконавчої влади на різних рівнях адміністративно-територіального устрою за принципом субсидіарності та розмежуванні повноважень між органами виконавчої влади та органами місцевого самоврядування на засадах децентралізації влади.

Як для України так і для Польщі характерним є трирівневий адміністративно-територіальний поділ. Рівень регіону в Україні область, в Польщі - воєводство. Однак після адміністративної реформи 1999 р. в Польщі кількість воєводств зменшилась із сорока дев'яти до шістнадцяти. В Україні залишилось, як і раніше, 24 області. Також для України характерна велика подрібненість територіальних громад, особливо на найнижчому рівні управління - малих містечок, селищ і сіл. Для України характерним є високий ступінь централізації, який передбачає систему трансфертів, що становить більшу частину бюджетів підпорядкованих органів виконавчої влади. Ця система бюджетних відносин має позитивну сторону, яка полягає в тому що місцеві бюджети узгоджуються із централізованим плануванням, а негативною стороною $\epsilon$ те, що органи виконавчої влади на рівні районів і регіонів залежні від центрального уряду в частині розпорядження бюджетними коштами [22]. 
В Польщі на рівні управління повітом існують певні особливості. Чіткий розподіл на законодавчому рівні прибутків між держбюджетом і місцевими бюджетами та фінансова самостійність повіту дає можливість органам територіальної влади самостійно формувати бюджет і прогнозувати подальший розвиток адміністративно-територіальної одиниці. Для польської моделі публічного управління властивий дуалізм для державної адміністрації та органів місцевого самоврядування тільки на рівні регіону. Окрім цього, формування нормативного, кадрового, бюджетного та контрольного механізмів управління та налагодження вертикальної і горизонтальної взаємодії між різними територіальними рівнями адміністративного поділу забезпечили створення ефективної моделі місцевого та регіонального управління і сформували баланс розподілу владних повноважень між місцевим самоврядуванням та державним управлінням. Подібність української моделі державного управління із польською моделлю публічного врядування полягає в тому, що на рівні регіону в Україні й воєводстві в Польщі присутній дуалізм влади як урядових структур так і місцевого самоврядування [13].

Найпоширенішим серед дослідників науково обгрунтованим та таким, що базується на комплексному підході, є виокремлення чотирьох основних моделей організації місцевого самоврядування - англосаксонської, континентальної, іберійської та радянської моделей.

Аналізуючи європейський досвід, українські реформатори, при виборі успішної моделі децентралізації, прийняли рішення, що польська модель децентралізації є найбільш наближеною до українських реалій і досвід польських реформ може бути найбільш корисним при проведенні реформ в Україні, як країни, яка досягла поставленої мети і здійснила реформу місцевого самоврядування, що за експертними оцінками спеціалістів Ради Свропи, є взірцем таких перетворень у Центрально-Східній Свропі.

Не дивлячись на те, що децентралізація влади як управлінський феномен здійснюється в кожному конкретному випадку у власний спосіб, відображаючи ті соціальні та історичні реалії, що детермінують певну соціально-управлінську модель, більшість науковців стверджують, що Україні має послугувати саме польський досвід 
реформування місцевого самоврядування. Вибір польської моделі децентралізації публічної влади викликаний також наступними причинами: по-перше, це сусідня держава, яка в багатьох аспектах подібна до України, зокрема територіально, є колишньою посткомуністичною державою, має подібні хронологічні рамки початку державного будівництва й проблеми 3 пошуку моделі державного управління; по-друге, в Польщі подібна до української система державного устрою: унітарна держава з республіканською формою правління, демократичним політичним режимом, але відрізняються форми державного правління: в Польщі - парламентська, в Україні парламентсько-президентська республіки; по-третє, досвід впровадження системи публічного врядування в Польщі $є$ успішним.

Основними моментами в реформуванні публічного управління в Польщі є децентралізація та субсидіарність Суть управлінського механізму полягає в тому, щоб місцеві питання вирішувалися місцевою громадою, а не державною владою [7].

Покладений принцип реформування місцевого самоврядування і публічної влади в Польщі став основою проведення адміністративно-територіальної реформи. У Концепції реформування місцевого самоврядування та територіальної організації влади в Україні зазначено шлях та способи адміністративно-територіального реформування, що грунтується на розмежуванні повноважень у системі органів місцевого самоврядування та органів виконавчої влади на різних рівнях адміністративно-територіального устрою за принципом субсидіарності та розмежуванні повноважень між органами виконавчої влади та органами місцевого самоврядування на засадах децентралізації влади [2].

Республіка Польща має трирівневий адміністративно-територіальний поділ, що є характерно і для України. Рівень регіону в Україні - область, в Польщі - воєводство. Однак після адміністративної реформи 1999 р. в Польщі кількість воєводств зменшилась із сорока дев' яти до шістнадцяти. В Україні залишилось, як і раніше, 24 області. В нашій державі існує велика подрібненість територіальних громад, особливо на найнижчому рівні управління - малих містечок, селищ і сіл. Найбільшим адміністративно-територіальним утворенням 
Польщі є воєводство (в Україні - регіон, область), для якого також характерний своєрідний владний дуалізм: між державною адміністрацією та органами місцевого самоврядування. Воєвода $є$ представником Ради Міністрів у воєводстві (регіоні) і на нього покладаються основні державницькі функції. Завдання воєводи полягає в реалізації державної політики. Позитивним у публічному управлінні $\epsilon$ право воєводи делегувати повноваження врядування на основі угоди місцевим органам самоврядування. Така самостійність прийняття рішень воєводою з питань розподілу владних повноважень на регіональному рівні свідчить про дієвість принципу децентралізації владних повноважень, закладених у Конституції Республіки Польща [8].

Окрім воєводи, функції державного управління виконують регіональні урядові органи об'єднаної адміністрації, органи необ'єднаної урядової адміністрації, органи місцевого самоврядування і їх асоціації за умови якщо це передбачено законодавством чи договором про делеговані повноваження. В Польщі на рівні управління повітом існують певні особливості. Зокрема, повноваження повіту полягають у доповненні повноважень гміни у вирішенні тих питань, яких гміна не в змозі вирішити самостійно. Врядування в повіті здійснюється радою, яка обирається населенням адміністративної одиниці. В управлінські функції ради повіту входить прийняття рішень 3 формування бюджету, визначення рівня податкового навантаження, розпорядження комунальною власністю і здійснення контролю, як і на рівні гміни. Рада повіту призначає управління повіту, що підзвітне тільки раді повіту. Важливо, що в разі повторного порушення Конституції чи законодавства Польщі радою повіту чи правлінням повіту Сейм на пропозицію Голови Ради Міністрів може розпустити такий територіальний орган влади.

Для польської моделі публічного управління властивий дуалізм для державної адміністрації та органів місцевого самоврядування тільки на рівні регіону. Окрім цього, формування нормативного, кадрового, бюджетного та контрольного механізмів управління та налагодження вертикальної і горизонтальної взаємодії між різними територіальними рівнями адміністративного поділу забезпечили створення ефективної моделі місцевого та регіонального управлін- 
ня і сформували баланс розподілу владних повноважень між місцевим самоврядуванням та державним управлінням. Подібність української моделі державного управління із польською моделлю публічного врядування полягає в тому, що на рівні регіону в Україні й воєводстві в Польщі присутній дуалізм влади як урядових структур так і місцевого самоврядування. Але в польській моделі рівень самостійності органів місцевого самоврядування вищий, особливо в бюджетній сфері та при вирішенні питань добробуту населення на місцевому рівні. В Україні присутній дуалізм влади на районному рівні. На рівні повіту в Польщі дуалізм влади відсутній $[5 ; 9]$.

Нівеляція дуалізму владних повноважень на районному рівні в Україні та запровадження місцевого самоврядування із відповідними бюджетними та управлінською автономією, разом із наглядовими функціями державного управління буде сприяти ефективності публічного врядування на рівні району. В цьому контексті важливим є прийняття Верховною Радою України від 31 серпня 2015 р. Постанови «Про попереднє схвалення законопроекту про внесення змін до Конституції України щодо децентралізації влади». В ст.118 Постанови зазначено, що виконавчу владу в районах і областях, у Києві та Севастополі буде покладено на префектів, призначення яких буде відбуватись за поданням Кабінету Міністрів України Президентом України. В повноваження префекта входять наглядові, координуючі, організаційні функції.

При становленні адміністративно-територіального поділу в Польщі, у першу чергу забезпечено формування базового територіального рівня влади на рівні гміни. Ключове значення для успішного проведення адміністративно-територіальної реформи отримали фінансова складова та розподіл комунальної власності на базовому рівні. На законодавчому рівні в Польщі було запроваджено чіткий механізм розподілу прибуткової частини бюджету між держбюджетом і місцевими бюджетами, що дало можливість органам територіальної влади на відміну від України, де формування місцевих бюджетів відбувається централізовано, самостійно формувати бюджет та прогнозувати подальший розвиток адміністративно-територіальної одиниці. Публічне управління повинно включати діяльність, яка 
б забезпечувала ефективне функціонування всієї системи органів державної влади і місцевого самоврядування, широке залучення різних зацікавлених сторін до розробки і реалізації державної політики, а також впровадження системи взаємного контролю. Це передбачає наявність необхідної умови - децентралізації влади.

Важливим аспектом реформування державного управління в Україні на районному та регіональному рівнях $є$ задекларований у Концепції принцип субсидіарності на основі децентралізації влади. В Україні державне управління на рівні району і області здійснюють органи державної адміністрації. Однак при формуванні виконавчих органів на рівні району і регіону закладено дуалістичний принцип. Враховуючи польський досвід, на районному рівні варто запровадити місцеве самоврядування з представницьким виборним органом у формі районної ради, яка формує районні виконавчі органи наділені відповідними повноваженнями в частині комунальної власності та бюджетної сфери. Контролюючі функції в частині забезпечення принципів відповідності нормативно-правовим актам України та господарності на рівні району і області забезпечував би інститут префектів. Впровадження такої моделі управління на рівні району, області забезпечить якісніше публічне управління, ефективне використання бюджетних коштів, розвиток інфраструктури та покращення соціально-економічної ситуації [14].

Детально проаналізувавши досвід реформи децентралізації Республіки Польща, варто зазначити, що позитивним моментом для України буде впровадження польської моделі фінансової децентралізації. Врахувавши позитивні результати, необхідно розробити ефективну бюджетну політику регіонів. Для цього передусім необхідно розмежувати витрати між рівнями бюджету (державного, обласного і районного). По-друге, мають бути розроблені та на законодавчій основі встановленні норми бюджетної забезпеченості на одного жителя регіону. По-третє, варто вдосконалити соціальні нормативи та фінансові норми, які б вивели соціальне забезпечення громадян на новий якісний рівень, вирішили питання бюджетної забезпеченості і визначення мінімального обсягу місцевого бюджету. Необхідно зазначити, що пріоритетними напрямами управління державними 
фінансами мають бути їх обгрунтоване формування, прозорий розподіл і перерозподіл та ефективне використання. Це буде сприяти ефективному управлінню бюджетними коштами в країні [16].

Насамперед вдосконалення потребує правова та інституційна база системи міжбюджетного фінансування. Наступним кроком повинна стати робота науковців, адже необхідною умовою є розробка методики розрахунку фінансування регіонів. Далі пропонується внести зміни до законів «Про місцеве самоврядування в Україні» та «Про місцеві державні адміністрації», де вказані повноваження місцевих органів, методика визначення обсягів фінансування, а також визначено поняття «комунальна власність» та «комунальне майно». Варто зазначити, що для кожного рівня органів місцевої влади потрібно окреслити коло відповідальності та міри покарання, так як контроль та відповідальність $є$ підгрунтям децентралізації. В результаті втілення зазначених пропозицій щодо фінансової децентралізації очікується створення нової системи місцевих бюджетів та міжбюджетних відносин, в основі яких повинна бути інституційна симетрія, що передбачає поєднання та взаємозв'язок економічних суб'єктів, які користуються суспільними благами, сплачують податки, і тих, хто приймає самостійно рішення про їі надання.

Отже, наявна система міжбюджетних відносин не відповідає сучасним вимогам, тому вона потребує подальшого реформування. Основними вимогами до системи міжбюджетних відносин є:

- обсяги трансфертних платежів окремих територіальних одиниць мають враховувати декілька індикаторів, які відображають реальні доходи і обгрунтовані видатки;

- базова дотація має сприяти фіскальній спроможності місцевих бюджетів;

- обсяг трансфертів повинен відповідати фінансовому забезпеченню макроекономічної фінансової стабільності регіону та сприяти його економічному зростанню.

По-друге, система міжбюджетних трансфертів має стимулювати місцеві органи влади формувати власні доходи у місцевих бюджетах. По-третє, трансфертна система повинна забезпечувати покриття вертикальних і горизонтальних дисбалансів. 
Таким чином, зробивши детальний огляд реалізації реформи децентралізації в Республіці Польща та плани, що обговорюються в Україні, то можна дійти висновку, що спільним являється остаточний результат проведеної реформи. Різниця полягає в тому, що за позитивним результатом реформи в Польщі стояло прагнення політиків досягти поставленої мети. Польща не потребувала укрупнення територіальних громад, так само непринциповим виявився розмір повітів - тож тут головним питанням було забезпечення повноважень та ресурсів, а не чисельність і площа, укрупнення ж потребував, насамперед, рівень воєводств, який в Україні принципових змін не вимагає.

Враховуючи досвід країн СС т азокрема успіхи Республіки Польща, варто запровадити місцеве самоврядування 3 представницьким виборним органом у формі районної ради, яка формує районні виконавчі органи наділені відповідними повноваженнями в частині комунальної власності та бюджетної сфери. Контролюючі функції в частині забезпечення принципів відповідності нормативно-правовим актам України та господарності на рівні району і області забезпечував би інститут префектів. Впровадження такої моделі управління на рівні району, області забезпечить якісніше публічне управління, ефективне використання бюджетних коштів, розвиток інфраструктури та покращення соціально-економічної ситуації [15].

Висновки. Таким чином, позитивний досвід країн СС і зокрема Республіки Польща щодо реформ свідчить про те, що децентралізація є важливим та невід'ємним інструментом економічного зростання та протидії корупції. Проте треба пам'ятати, що моделі, яку можна було б на сто відсотків імплементувати в Україні не існує по тій причині, що кожна країна має свої особливості здійснення реформ. Головною перешкодою в перейнятті польського досвіду є інший адміністративний поділ, нестабільна соціально-економічна та політична ситуація, непідготовлена законодавча база, а подекуди незацікавленість місцевих посадовців, нерозуміння з боку сільських голів, відсутність кваліфікованих кадрів, корупція тощо. Спільним $є$ запровадження триступеневої структури місцевого самоврядування як в Польщі, так і в Україні, а також - посади сільського старости. 
Таким чином, аналіз досвіду європейських країн та актуальних наукових досліджень дозволяють виокремити такі передумови успішної імплементації децентралізаційних процесів для створення ефективної моделі управління в системі децентралізованої влади України:

- утвердження принципу верховенства права;

- визнання та гарантії місцевого самоврядування;

- рівний правовий захист усіх форм власності;

- демократичне й ефективне виборче законодавство;

- незалежність, ефективність, доступність і прозорість судової системи, функціонування інститутів адміністративного судочинства;

- досконалий бюджетний процес та висока фінансова дисципліна;

- наявність адекватних соціальних стандартів;

- розвинутий громадський сектор або стійка тенденція до його розвитку

Зважаючи на вищезазначене, можна стверджувати, що історичний досвід розвинутих демократій, інституалізований в документах Ради Європи, зокрема в Свропейській хартії місцевого самоврядування, був вагомим чинником реформування системи публічного управління в європейських країнах. Вважаємо, що грунтовне вивчення та врахування європейського досвіду децентралізації системи управління, публічного адміністрування й територіальної організації влади сприятиме ефективному реформуванню вітчизняної системи місцевого самоврядування, зокрема: вдосконаленню конституційно-правових засад територіальної організації влади в Україні, поглибленню децентралізації та утвердженню реальних повноважень органами місцевого самоврядування через їх делегування i демократизацію процесів управління [12].

Зміни, які наразі відбуваються в українському суспільстві, вказують на те, що Україна готова здійснювати реформу децентралізації публічної влади та адміністрування, яка в процесах розвитку громадянського суспільства $є$ формою чіткої фіксації процесу відокремлення суспільства 3-під держави та слугує своєрідною вимірювальною лінійкою для демократизації системи державного управ- 
ління, створюючи своєрідний технологічний базис для становлення громадянського суспільства, актуалізуючи зміни в правовому полі в бік децентралізації - що $є$ кроком до впровадження демократичних цінностей та стабільного зростання добробуту громадян. Процес децентралізації управління, як свідчать уроки Республіки Польща, повинні стати рушійною силою оптимального розвитку місцевого самоврядування у вигляді територіальних громад, тобто, успішність цієї реформи, є запорукою розвитку свободи, демократії та громадянського суспільства в Україні [19].

Стаття надійшла до редакціi: 23.03.2019

\section{IMPLEMENTATION OF THE EXPERIENCE OF THE REPUBLIC OF POLAND IN THE PROCESS OF IMPROVEMENT OF DECENTRALIZATION OF THE PUBLIC AUTHORITY AND ADMINISTRATION IN UKRAINE}

Mykhaylo Bagmet, Doctor of History, professor Black Sea National University of Petro Mohyla Mykolaiv, Ukraine

Oleksandr Shtyrov, $\mathrm{PhD}$ in Public Administration, Associate professor, Institute of Public Administration, Petro Mohyla Black Sea National University, Mykolaiv, Ukraine

Yana Harhaun, PhD of History, Black Sea National University of Petro Mohyla Mykolaiv, Ukraine

The article examines the experience of the Republic of Poland in implementing the decentralization reform, as well as the possibilities for its implementation in Ukraine. In addition, the study includes an analysis of the decentralization reform in Ukraine. The authors of the article emphasize the necessity of borrowing from Ukraine the experience of Poland, proves that Ukraine is ready to implement the reform of decentralization of public administration and administration. Based on the research, it was concluded that the implementation of the positive 
experience of the Republic of Poland will contribute to the formation of civil society, as the success of the reform of decentralization of public administration and administration is a pillar of the development of freedom, democracy and civil society in Ukraine.

Decentralization of public administration and administration over the past few years has become a very topical and popular issue among scholars and politicians. Moreover, this trend concerns not only the countries with established democratic traditions, but also the countries of the former socialist camp, where for a long time there was a centralized authoritarian government, including in the issues of local development. The strategic course of Ukraine, aimed at European integration, requires a modern model of public administration. The experience of European countries successfully demonstrates that decentralization of public administration and administration is the most effective instrument for modernizing public administration. However, in practice in Ukraine decentralization and development of territorial communities have long been not considered as a serious factor in the development of the country as a whole.

This suggests the need to study the reform of decentralization in Poland and the possibility of its implementation in Ukraine.

Keywords: decentralization, reform, Republic of Poland, Ukraine, implementation, civil society.

\section{Received: 23.03.2019}

\section{References}

1. Barvitskyi V. (2006). U poshukakh shliakhiv formuvannia diiezdatnykh terytorialnykh hromad: mizhnarodnyi dosvid. [In search of ways of formation of capable territorial communities: international experience]. Problemy detsentralizatsii: natsionalnyi ta mizhnarodnyi dosvid. Zbirnyk materialiv ta dokumentiv / (Kyiv, 2006 r.), 744. [in Ukrainian]

2. BoryslavskaO.,ZaverukhaE.,ZakharchenkoI.(2012).Detsentralizatsiia publichnoi vlady: dosvid yevropeiskykh krain ta perspektyvy Ukrainy. [Decentralization of public power: the experience of European countries and the prospects of Ukraine]. Naukove vydannia. Retrieved from: http://despro.org. 
ua/media/upload/decentral_zac_ya_publ_chno_vladi_dosv_d_evropeyskih_ derzhav_ta_perspektivi_ukra_ni\%282\%29.pdf [in Ukrainian].

3. Demchenko O.L., Yakovenko K.A. (2018). Evropeiskyi dosvid biudzhetnoi detsentralizatsii ta perspektyvy dlia Ukrainy. [European experience of budget decentralization and prospects for Ukraine]. Економіка і суспільство. Науковий збірник. Vol. \#16. p. 724-730. [in Ukrainian]

4. Krat M., \& Sofii O. (2017). Porivnialnyi analiz protsesu detsentralizatsii Ukrainy ta Polshchi [Comparative analysis of the process of decentralization of Ukraine and Poland]. Lviv: Yevropeiskyi dialoh Retrieved from: http:// dialog.lviv.ua/wp-content/uploads/2017/10/Porivnyalniy-analiz-protsesudetsentralizatsiyi-Ukrayini-ta-Polshhi.pdf [in Ukrainian]

5. Malynovs'kyy V. Uroky pol's'koyi administratyvno-terytorial'noyi reformy dlya Ukrayiny / V. Malynovs'kyy // Derzhavne ta munitsypal'ne upravlinnya $\mathrm{v}$ umovakh polityko-administratyvnoyi reformy : materialy nauk. prakt. konf. Tezy dop. (17-18 travnya 2007 r.) / Vidpov. red. V. Malynovs'kyy. Luts'k : Volyns'ka oblasna drukarnya, 2007. - S. 15-18

6. Matviienko V. Ya. (2000). Prohnostyka: prohnozuvannia sotsialnykh ta ekonomichnykh protsesiv: teoriia, metodyka, praktyka [Prognostics: forecasting social and economic processes: theory, methodology, practice]. Kyiv: Ukr. Propylei [in Ukrainian]

7. Mendzh, M. V., Rohach O. Ya. (2015). Detsentralizatsiya publichnoyi vlady ta finansove vyrivnyuvannya rozvytku hromad: yevropeys'kyy ta natsional'nyy dosvid // Porivnyal'no-analitychne pravo. - 2015. - №5. - S. 65-70. [in Ukrainian]

8. Minchenko, R.M. Problemy detsentralizatsiyi derzhavnoyi vlady i yikh vzayemodiya z mistsevym samovryaduvannyam v Ukrayini / R.M. Minchenko // Derzhava i pravo. - Vol. 39. - 452 s. [in Ukrainian]

9. Pro poperednye skhvalennya zakonoproektu pro vnesennya zmin do Konstytutsiyi Ukrayiny shchodo detsentralizatsiyi vlady : Postanova Verkhovnoyi Rady Ukrayiny vid 31 serpnya 2015 roku № 656-VIII. - Retrieved from: http://zakon4.rada.gov.ua/laws/show/656-19 [in Ukrainian]

10. Pro skhvalennya Kontseptsiyi reformuvannya mistsevoho samovryaduvannya ta terytorial'noyi orhanizatsiyi vlady v Ukrayini [Elektronnyy resurs] : Rozporyadzhennya Kabinetu Ministriv Ukrayiny vid 1 kvitnya 2014 r. № 333$\mathrm{r}$ - Retrieved from: http://zakon5.rada.gov.ua/laws/show/333-2014-\%D1\%80 [in Ukrainian]

11. Pukhtynskyi, M.O. (2009). Zarubizhnyi dosvid orhanizatsii roboty mistsevoi vlady [Foreign experience in organizing the work of local authorities]. Kharkiv: Magistr [in Ukrainian] 
12. Roman, V. F. (2014). Osoblyvosti detsentralizatsiyi ta dekontsentratsiyi vlady: teoretychnyy aspekt [Features of decentralization and deconcentration of power: the theoretical aspect] Efektyvnist derzhavnoho upravlinnya Effectiveness of public administration, 38, 92-98. - Retrieved from: http://nbuv. gov.ua/j-pdf/efdu_2014_38_11.pdf. [in Ukrainian]

13. Rosolyak O. (2016). Finansova detsentralizatsiya: dosvid Pol'shchi ta realiyi Ukrayiny / Aktual'ni problemy pravoznavstva - Actual problems of lawVyp. 2. - S. 66-70. - Rezhym dostupu: http://nbuv.gov.ua/UJRN/ aprpr_2016_2_14. [in Ukrainian]

14. Sinkevych YE. H. (2016). Ukrayina i pol's'kyy dosvid ekonomichnoyi intehratsiyi do EU. [Local government in Poland]. Chornomors'kyy litopys : nauk. zhurn. - Black Sea Chronicle: Scientific Journal: Vol. 11, pp.75-78. [in Ukrainian]

15. Soroka, S. V. (2015). Senat u systemi orhaniv derzhavnoyi vlady Respubliky Pol'shcha v 1989-2009 rokakh [Senate in the system of state authorities of the Republic of Poland in 1989-2009]. Naukovi pratsi-Scientific works, Vol. 263. \#252, 130-136 [in Ukrainian]

16. Svyanyevych, P. (2014). Mistseve samovryaduvannya v Pol'shchi [Local government in Poland]. Retrieved from: http://www.largis.ldp.lviv.ua/ ukraine/ documu.htm[in Ukrainian]

17. Tarasenko, T. (2014). Problema detsentralizatsii v reformuvanni mistsevoho samovriaduvannia $v$ Ukraini [The problem of decentralization in the reform of local self-government in Ukraine]. Державне управління місцевого самоврядування- State administration of local self-government, 2(21), [in Ukrainian]

18. Tkachuk, A.F. (2015). Latviia: dovha doroha reform. [Latvia: a long road to reform]. Робочi записки Kyiv: Lehalnyi status [in Ukrainian]

19. Uroky Pol'shchi v pytannyakh finansovoyi detsentralizatsiyi. Retrieved from: http://centre-reform.org/novini/uroki-polshh\%D1\%96-v-pitannyahf\%D1\%96nansovo\%D1\%97-decentral\%D1\%96zac\%D1\%96\%D1\%97.html. [in Ukrainian]

20. Yak provely reformu Як провели реформу адміністративно-територіального устрою та місцевого самоврядування у Латвії. Retrieved from: http://www.csi.org.ua/?p=4802. [in Ukrainian]

21. Yevropeys'ka khartiya mistsevoho samovryaduvannya vid 15.10 .1985 // Ofitsiynyy visnyk Ukrayiny . -2015. -№24; 2013. - № 39. - p. 1418. [in Ukrainian]

22. Behey, I.P. (2015). Vykorystannya dosvidu Polshchi dlya vyznachennya osoblyvostey reformuvannya derzhavnoho upravlinnya na rayonnomu ta 
rehionalnomu rivnyakh. [Using the experience of Poland to determine the peculiarities of reforming public administration at the district and territorial levels]. Aspekty publichnoho upravlinnya. - Vol. 9 (23). 57-63.[in Ukrainian]

23. Konstytucja Rzeczypospolitej Polskiej z 2 kwietnia 1997 roku. Retrieved from: http://www. sejm.gov.pl/prawo/konst/polski/konl.htm [in Poland]

\section{Відомості про авторів / Information about the Authors}

Багмет Михайло Олександрович: Чорноморський національний університет імені Петра Могили: вул. 68 Десантників 10, Миколаїв, 54003, Україна.

Mykhaylo Bagmet: Black Sea National University of Petro Mohyla: 68 Desantnykiv str. 10, Mykolaiv, 54003, Ukraine.

\section{ORCID.ORG/ 000-0003-2386-4488}

\section{E-mail: mykhaylo.bagmet@gmail.com}

Штирьов Олександр Миколайович: Чорноморський національний університет імені Петра Могили: вул. 68 десантників 10, Миколаїв, 54003, Україна.

Oleksandr Shtyrov: Black Sea National University of Petro Mohyla: 68 Desantnykiv str. 10, Mykolaiv, 54003, Ukraine.

ORCID. ORG./ 0000-0002-7627-3721

\section{E-mail: bratislava@ukr.net}

Гаргаун Яна Ігорівна: Чорноморський національний університет імені Петра Могили: вул. 68 десантників 10, Миколаїв, 54003, Україна.

Yana Harhaun: Black Sea National University of Petro Mohyla: 68 Desantnykiv str. 10, Mykolaiv, 54003, Ukraine.

\section{E-mail: yana14karpiuk@gmail.com}

